\title{
Methylation profiling of ductal carcinoma in situ and its relationship to histopathological features
}

Jia-Min B Pang ${ }^{1,2^{*}}$, Siddhartha Deb ${ }^{1,2}$, Elena A Takano ${ }^{1}$, David J Byrne ${ }^{1}$, Nicholas Jene ${ }^{1}$, Alice Boulghourjian4, Anne Holliday ${ }^{4}$, Ewan Millar ${ }^{4,5,6,8}$, C Soon Lee ${ }^{7,8,9}$, Sandra A OToole ${ }^{4,7,10}$, Alexander Dobrovic ${ }^{1,2,11}$ and Stephen B Fox ${ }^{1,2,3}$

\begin{abstract}
Introduction: DNA methylation is a well-studied biomarker in invasive breast cancer, but its role in ductal carcinoma in situ (DCIS) is less well characterized. The aims of this study are to assess the methylation profile in DCIS for a panel of well-characterized genes that are frequently methylated in breast cancer, to investigate the relationship of methylation with pathological features, and to perform a proof-of-principle study to evaluate the practicality of methylation as a biomarker in diagnostic DCIS material.
\end{abstract}

Methods: Promoter CpG island methylation for a panel of 11 breast cancer-related genes was performed by methylation-sensitive high resolution melting (MS-HRM). Formalin-fixed, paraffin-embedded (FFPE) biopsies from 72 samples of pure DCIS (DCIS occurring in the absence of synchronous invasive carcinoma), 10 samples of mixed DCIS (DCIS adjacent to invasive carcinoma), and 18 samples of normal breast epithelium adjacent to a DCIS lesion were micro-dissected prior to DNA extraction.

Results: Methylation was seen for all the tested genes except BRCA1. RASSF1A was the most frequently methylated gene ( $90 \%$ of DCIS samples) and its methylation was associated with comedo necrosis $(p=0.018)$. Cluster analysis based on the methylation profile revealed four groups, the highly methylated cluster being significantly associated with high nuclear grade, HER2 amplification, negative estrogen receptor (ER) a status, and negative progesterone receptor (PgR) status, $(p=0.038, p=0.018, p<0.001, p=0.001$, respectively). Methylation of APC ( $p=0.017), C D H 13$ $(\mathrm{p}=0.017)$, and RAR $(\mathrm{p}<0.001)$ was associated with negative ERa status. Methylation of CDH13 ( $<<0.001)$, and RARB ( $p=0.001)$ was associated with negative PgR status. Methylation of APC $(p=0.013)$ and CDH13 $(p=0.026)$ was associated with high nuclear grade. Methylation of CDH13 $(p=0.009)$, and RARß $(p=0.042)$ was associated with HER2-amplification.

Conclusions: DNA methylation can be assessed in FFPE-derived samples using suitable methodologies. Methylation of a panel of genes that are known to be methylated in invasive breast cancer was able to classify DCIS into distinct groups and was differentially associated with phenotypic features in DCIS.

\section{Introduction}

Ductal carcinoma in situ (DCIS), a non-invasive form of breast cancer and a non-obligate precursor of invasive carcinoma of the breast, has both morphological and biological heterogeneity. Current markers of poor prognosis to help select the use of adjuvant therapies are largely based on clinical and histopathological parameters, and

\footnotetext{
* Correspondence: jia-min.pang@petermac.org

'Department of Pathology, Peter MacCallum Cancer Centre, St Andrews

Place, Melbourne, VIC 3002, Australia

${ }^{2}$ Department of Pathology, University of Melbourne, Grattan Street, Parkville,

Melbourne, VIC 3010, Australia

Full list of author information is available at the end of the article
}

include young age, large tumour size, high nuclear grade, presence of comedo necrosis, negative hormone receptor status, and HER2 amplification [1,2]. However, these clinicopathological features are insufficient in predicting which patients will experience recurrence of DCIS or progress to invasive carcinoma [1-3]. Therefore, more informative and robust prognostic markers are required, which also need to be compatible with small amounts of often degraded, formalin-fixed, paraffin-embedded (FFPE)-derived DNA, as typically only a sparse amount of material is available for analysis from DCIS lesions.

DNA methylation is an epigenetic modification where a methyl group is added to the 5-carbon position of 
cytosine and is a mechanism of modulating gene expression. Alterations in methylation patterns in cancer are characterized by global hypomethylation and gene-specific promoter hypermethylation. Promoter hypermethylation may result in gene silencing, and in cancer this can be a mechanism of tumour suppressor gene inactivation. Promoter methylation frequently follows a tumour-specific pattern and has been reported to be a useful biomarker in several types of cancer, including invasive breast cancer [4]. Several studies have linked methylation of specific genes to DCIS phenotypes, including APC [5], CDH1 [6], FOXC1 [7,8], GSTP1 [7-9], RAR $\beta$ [5], and RASSF1A [7,8]. However, most of these studies have examined methylation in a small number of pure DCIS cases [5,7-10], or combined invasive breast cancer cases together with DCIS cases to establish the relationship between methylation and phenotype $[7,8]$. Therefore, the true frequency and utility of DNA methylation biomarkers in DCIS has yet to be established [11].

The aims of this study were to document the frequency and level of methylation of a panel of eleven breast cancer-related genes to determine whether these methylated genes are associated with histopathological parameters. These genes were chosen because methylation of the genes have previously been identified as important in invasive breast cancer by The Cancer Genome Atlas Network (TCGA) [12] and/or associated with prognosis in DCIS (APC [5], CDH1 [6], FOXC1 [7], GSTP1 [9], $R A R \beta$ [5], RASSF1A [7]) or invasive carcinoma (BRCA1 [13,14], CDH13 [15], MAL [16], TWIST1 [17], WIF1 [18]). The goal of the study was to improve our understanding of methylation in in situ breast cancer, to understand its relation to important histopathological variables and conduct a proof-of-principle study to assess the potential of methylation status as a biomarker in patients with DCIS

\section{Materials and methods Patients and samples}

FFPE blocks were obtained from primary DCIS cases from Peter MacCallum Cancer Centre and Royal Prince Alfred Hospital. Approval for the project was obtained from the ethics committees of Peter MacCallum Cancer Centre (project number 02/26 and 10/16) and Royal Prince Alfred Hospital (project HREC/11/RPAH/126), including a waiver of consent for the use of archival material for research. A total of 72 pure DCIS samples (DCIS occurring in the absence of synchronous invasive carcinoma), 10 mixed DCIS samples (DCIS adjacent to invasive carcinoma) and 18 samples of normal breast epithelium (including 16 normal samples matched to DCIS from the same paraffin block) were obtained from 79 patients (69 patients with pure DCIS and 10 patients with mixed DCIS). Patient flow in the study is shown in Additional file 1.
Patient and sample characteristics are summarized in Table 1. All patients were female. The median age of the cohort was 54 years (range 29 to 82 years), and median tumour size was $32.8 \mathrm{~mm}$ (range 5.0 to $145.0 \mathrm{~mm}$ ).

$\mathrm{H} \& \mathrm{E}$-stained sections of the FFPE blocks used for DNA extraction were reviewed by a pathologist. The nuclear grade of DCIS was determined according to the guidelines described in the WHO Classification of Tumours of the Breast, $4^{\text {th }}$ edition [19]. Immunohistochemical (IHC) staining for estrogen receptor (ER) $\alpha$, progesterone receptor (PgR), and cytokeratin 5 (CK5) and HER2 silver in situ hybridization (SISH) were performed as previously described [20,21]. Tumours were considered to be ER $\alpha$ positive and PgR-positive if at least $10 \%$ of tumour cells showed nuclear staining, and were considered HER-2 amplified if there were at least six dots or large clusters of dots in the tumour nuclei [22].

Tumours were classified into intrinsic subtypes by IHC staining of tissue microarrays (TMA), based on criteria for invasive carcinomas of Nielsen et al. [23] and Cheang et al. [24], and similar to those previously used in DCIS [25-27]. Tumours exhibiting ER $\alpha$ or PgR positivity in the absence of HER2 amplification were considered of luminal subtype, human epidermal growth factor receptor-2 (HER2) subtype consisted of tumours with HER2 amplification, regardless of ER $\alpha$ and PgR status, basal-like subtype consisted of triple negative (ER $\alpha$ negative, PgR negative, HER2 non-amplified) tumours with any degree of CK5 membranous staining, and negative subtype tumours consisted of triple-negative tumours without CK5 staining.

\section{DNA preparation and bisulfite modification}

Areas of DCIS and adjacent normal breast epithelium were needle micro-dissected with the aid of a dissecting microscope from up to 72 methyl green-stained $7 \mu$ m-thick parallel sections. No invasive carcinoma was present in the available paraffin block of the ten cases of mixed DCIS. Genomic DNA was extracted from the micro-dissected tissues using the QIAamp DNA Blood Mini Kit (Qiagen, Hilden, Germany) as previously described [28]. Five hundred nanograms of genomic DNA were bisulfite-modified using the MethylEasy Xceed Rapid DNA Bisulphite Modification Kit (Human Genetic Signatures, Sydney, Australia) according to the manufacturer's instructions. The bisulfite-modified DNA was eluted to achieve a final concentration of $10 \mathrm{ng} / \mu \mathrm{L}$. Universal Methylated DNA (CpGenome Universal Methylated DNA, Millipore, Billerica, MA, USA) and whole genome amplified (WGA) peripheral blood mononuclear DNA (Ready-ToGo GenomiPhi V3 DNA Amplification Kit, GE Healthcare, Buckinghamshire, UK) were bisulfite-modified as above and used as fully methylated (100\%) and unmethylated (0\%) controls, respectively. Methylation standards (50\%, 
Table 1 Characteristics of the cohort

\begin{tabular}{|c|c|c|c|c|}
\hline Feature & & $\begin{array}{l}\text { Pure ductal carcinoma in situ } \\
(n=72)\end{array}$ & $\begin{array}{l}\text { Mixed ductal carcinoma in situ } \\
(n=10)\end{array}$ & $\begin{array}{l}\text { All ductal carcinoma in situ } \\
(\mathrm{n}=82)\end{array}$ \\
\hline \multirow[t]{3}{*}{ Age } & Median, years & 54.0 & 53.0 & 54.0 \\
\hline & Range, years & 29 to 82 & 42 to 67 & 29 to 82 \\
\hline & No data & $14 / 69$ & $1 / 10$ & $15 / 79$ \\
\hline \multirow[t]{2}{*}{ Lesion size } & Median, mm & 32.0 & 40.0 & 32.8 \\
\hline & Range, mm & 5 to 145 & 11 to 103 & 5 to 145 \\
\hline \multirow[t]{3}{*}{ Nuclear grade } & High & $35 / 72(48.6 \%)$ & $4 / 10(40 \%)$ & $39 / 82(47.6 \%)$ \\
\hline & Intermediate & $31 / 72(43.1 \%)$ & $6 / 10(60 \%)$ & $37 / 82(45.1 \%)$ \\
\hline & Low & 6/72 (8.3\%) & 0/10 (0\%) & $6 / 82(7.3 \%)$ \\
\hline \multirow{6}{*}{$\begin{array}{l}\text { Predominant architectural } \\
\text { pattern }\end{array}$} & Solid & $37 / 72(51.4 \%)$ & $10 / 10(100 \%)$ & 47/82 (57.3\%) \\
\hline & Cribriform & $17 / 72(23.6 \%)$ & 0/10 (0\%) & 17/82 (20.7\%) \\
\hline & Micropapillary & 11/72 (15.3\%) & 0/10 (0\%) & $11 / 82(13.4 \%)$ \\
\hline & Clinging & $4 / 72(5.6 \%)$ & 0/10 (0\%) & $4 / 82(4.9 \%)$ \\
\hline & $\begin{array}{l}\text { Cancerisation of } \\
\text { lobules }\end{array}$ & $2 / 72(2.8 \%)$ & $0 / 10(0 \%)$ & $2 / 82(2.4 \%)$ \\
\hline & Papillary & $1 / 72(1.4 \%)$ & 0/10 (0\%) & $1 / 82(1.2 \%)$ \\
\hline \multirow[t]{2}{*}{ Comedo necrosis } & Present & 29/72 (40.3\%) & $6 / 10(60 \%)$ & $35 / 82(42.7 \%)$ \\
\hline & Absent & 43/72 (59.7\%) & $4 / 10(40 \%)$ & $47 / 82(57.3 \%)$ \\
\hline \multirow[t]{3}{*}{ Estrogen receptor status } & Positive & $48 / 67(71.6 \%)$ & $7 / 8(87.5 \%)$ & $55 / 75(73.3 \%)$ \\
\hline & Negative & 19/67 (28.4\%) & $1 / 8(12.5 \%)$ & $20 / 75(26.7 \%)$ \\
\hline & No data & $5 / 72$ & $2 / 10$ & $7 / 82$ \\
\hline \multirow{3}{*}{$\begin{array}{l}\text { Progesterone receptor } \\
\text { status }\end{array}$} & Positive & 40/67 (59.7\%) & $3 / 8(37.5 \%)$ & 43/75 (57.3\%) \\
\hline & Negative & 27/67 (40.3\%) & $5 / 8(62.5 \%)$ & $32 / 75(42.7 \%)$ \\
\hline & No data & $5 / 72$ & $2 / 10$ & $7 / 82$ \\
\hline \multirow[t]{3}{*}{ HER2 amplification } & Amplified & 20/67 (29.9\%) & $2 / 8(25 \%)$ & $22 / 75$ (29.3\%) \\
\hline & Non-amplified & 47/67 (70.1\%) & $6 / 8(75 \%)$ & $53 / 75(70.7 \%)$ \\
\hline & No data & $5 / 72$ & $2 / 10$ & $7 / 82$ \\
\hline \multirow[t]{5}{*}{ Intrinsic subtype } & Luminal & $38 / 67$ (56.7\%) & $6 / 8(75 \%)$ & $44 / 75$ (58.7\%) \\
\hline & HER2 & 20/67 (29.9\%) & $2 / 8(25 \%)$ & $22 / 75$ (29.3\%) \\
\hline & Basal & 2/67 (3.0\%) & 0/8 (0\%) & $2 / 75(2.6 \%)$ \\
\hline & Negative & $7 / 67(10.4 \%)$ & 0/8 (0\%) & $7 / 75(9.3 \%)$ \\
\hline & No data & $5 / 72$ & $2 / 10$ & $7 / 82$ \\
\hline
\end{tabular}

$25 \%$, and $10 \%$ methylated) were prepared by diluting fully methylated DNA into unmethylated DNA.

Methylation-sensitive high resolution melting (MS-HRM) Methylation analysis was performed using MS-HRM, a robust, real-time PCR-based methodology which allows semiquantitative assessment of homogeneous methylation and identification of heterogeneous methylation [29,30]. This method distinguishes between methylated and unmethylated templates based on melting profiles conferred by sequence alterations as a result of bisulfite modification. Methylated templates contain more cytosines compared with unmethylated templates after bisulfite conversion and therefore melt at a higher temperature. Heterogenous methylated templates are identified from complex melting patterns that arise as a consequence of heteroduplex formation [31]. Examples are shown in Additional file 2.

MS-HRM primers were designed according to guidelines previously described [32]. Primer sequences are listed in Additional file 3 . The PCR reaction mixture consisted of $1 \times$ PCR buffer (Qiagen, Hilden, Germany), 1.5 to $3.0 \mathrm{mM}$ $\mathrm{MgCl}_{2}$ (Qiagen), $200 \mu \mathrm{M}$ dNTP mix (Fisher Biotech, Perth, Australia), 200 to $400 \mathrm{nmol} / \mathrm{L}$ forward and reverse primers, 
$1 \times$ SYTO9 intercalating dye (Life Technologies, Carlsbad, CA, USA), 0.5U HotstarTaq polymerase (Qiagen), and 10 to $20 \mathrm{ng}$ of bisulfite modified DNA, in a total reaction volume of $20 \mu \mathrm{L}$. PCR amplification and high-resolution melting were performed using the Rotor-Gene Q (Qiagen). PCR and high resolution melting conditions are listed in Additional file 4. All assays were performed in duplicate with fully methylated, $50 \%, 25 \%, 10 \%$, and fully unmethylated DNA standards and non-template and non-bisulfitemodified genomic DNA controls.

Homogeneous methylation was scored as low $(<10 \%)$, moderate $(10 \%$ to $<50 \%)$, and high $(\geq 50 \%)$ level methylation. Heterogeneous methylation was scored as low-level or high-level heterogeneous methylation depending on the sample profile extension into the fully methylated profile (examples in Additional file 2). To compensate for non-specific background methylation, only samples with moderate- and high-level homogeneous methylation or high-level heterogeneous methylation were considered methylated. The average methylation index (AMI) for each sample was also calculated, which is similar to the cumulative methylation index described by Fackler et al. [33], but normalized for the number of genes assessed. Methylation levels at or close to $0 \%, 10 \%, 25 \%, 50 \%$, and $100 \%$ were scored as such. Low heterogeneous methylation and $<10 \%$ homogeneous methylation were scored as $0 \%$, and $10 \%$ to $25 \%, 25 \%$ to $50 \%$, and $50 \%$ to $100 \%$ methylation were scored as $18 \%, 38 \%$, and $75 \%$, methylation respectively. High-level heterogeneous methylation, which is not possible to quantify, was assigned an arbitrary score of $25 \%$ methylation.

\section{Statistical analysis}

Comparisons of continuous data between two groups, and more than two groups were evaluated by the MannWhitney $U$-test and the Kruskal-Wallis test, respectively. Fisher's exact probability test was used to assess $2 \times 2$ contingency tables and the $x^{2}$ test for independence was used for variables with three or more categories. For each comparison, a two-tailed $P$-value of 0.05 or less was considered to be statistically significant. All statistical analyses were performed using IBM SPSS version 22.0 (IBM Corporation, Armonk, NY, USA). Unsupervised hierarchical cluster analysis with average linkage was performed giving equal weighting to all genes and samples, with the exception of BRCA1 which was universally unmethylated and therefore removed from the analysis. The samples were filtered to include only those with methylation data for at least nine of the eleven genes. The cluster analysis was performed and heat map generated using Gene Cluster 3.0 and TreeView 1.60, respectively (Michael Eisen, University of California, USA). Histograms were generated using GraphPad Prism 6 (La Jolla, CA, USA).

\section{Results}

\section{Histopathological features of DCIS}

There were $47.6 \%, 45.1 \%$, and $7.3 \%$ of DCIS samples of high, intermediate and low nuclear grade, respectively. The most frequent architectural pattern was solid type (47/82, 57.3\%), followed by cribriform (17/82, 20.7\%), and micropapillary $(11 / 82,13.4 \%)$ patterns. The remainder of the samples showed clinging DCIS (4/82, 4.9\%), cancerisation of lobules $(2 / 82,2.4 \%)$ and papillary DCIS $(1 / 82$, $1.2 \%)$. Comedo-type necrosis was present in $42.7 \%(35 / 82)$ of DCIS samples. Fifty-five DCIS samples (55/75, 73.3\%) were ER $\alpha$-positive, and 43 samples $(43 / 55,57.3 \%)$ were PgR-positive. HER2 amplification was present in 22 samples $(22 / 75,29.3 \%)$. Luminal subtype accounted for $58.7 \%$ of samples (44/75), HER2 subtype 29.3\% (22/75), negative subtype $9.3 \%$ (7/75), and basal-like subtype $2.7 \%(2 / 75)$.

\section{Methylation status in normal, pure DCIS, and mixed DCIS samples}

DCIS samples had a significantly greater number of genes methylated (a median of 4 genes methylated, range 0 to 8 genes) compared with adjacent normal breast epithelium samples (median 0 genes methylated, range 0 to 2 genes) $(P<0.001)$. There was no significant difference in the number of genes methylated per sample between pure DCIS (median 4.5 genes, range 0 to 8 genes) and mixed DCIS samples (median 3 genes, range 2 to 8 genes) $(P=0.87)$. Among all DCIS, RASSF1A methylation was present in 90\% (72/80) of samples, CDH13 in 53.8\% (43/80), MAL in $49.4 \%(39 / 79), A P C$ in $48.8 \%(39 / 80)$, WIF1 in $48.8 \%$ (39/80), GSTP1 in $47.5 \%$ (38/80), TWIST1 in 40.7\% (33/81), RAR $\beta$ in $37 \%$ (30/81), and FOXC1 methylation in $11.3 \%$ $(9 / 80)$ of samples. $C D H 1$ methylation was rare $(2.5 \%, 2 / 79)$ (Table 2, Figure 1).

There was no difference in methylation in samples from patients younger than 50 years compared with older patients $(P>0.05$, data not shown). In addition, there was no difference in methylation between small DCIS tumours $(<20 \mathrm{~mm}[1])$ and larger tumours $(P>0.05$, data not shown). No BRCA1 methylation was present in any of the DCIS samples (Table 2).

In the normal breast epithelium samples, only WIF1 methylation $(27.8 \%, 5 / 18), C D H 13(5.6 \%, 1 / 18)$, and TWIST1 (5.9\%, 1/17) methylation were identified (Table 2, Figure 1). For all methylated normal samples, the corresponding DCIS tumour also was methylated for the same gene, apart from one case (sample S25) where the normal tissue showed heterogeneous methylation for WIF1 while the DCIS was unmethylated (Additional file 5).

\section{Association of methylation with DCIS phenotype}

Methylation of $A P C$ and $C D H 13$ was significantly associated with high nuclear grade $(P=0.013$ and $P=0.026$ 
Table 2 Frequency and level of methylation of genes by sample type

\begin{tabular}{|c|c|c|c|c|c|c|c|c|c|}
\hline \multirow[b]{3}{*}{ Gene } & \multirow[b]{3}{*}{ Sample type } & \multirow{2}{*}{\multicolumn{3}{|c|}{$\begin{array}{l}\text { Negative for methylation } \\
\text { Frequencies (\%) }\end{array}$}} & \multirow{2}{*}{\multicolumn{5}{|c|}{ Positive for methylation }} \\
\hline & & & & & & & & & \\
\hline & & $\begin{array}{l}\text { No } \\
\text { methylation }\end{array}$ & $\begin{array}{l}\text { Low } \\
\text { heterogenous } \\
\text { methylation }\end{array}$ & $\begin{array}{l}\text { Low } \\
\text { homogenous } \\
\text { methylation }\end{array}$ & $\begin{array}{l}\text { High } \\
\text { heterogenous } \\
\text { methylation }\end{array}$ & $\begin{array}{l}\text { Moderate } \\
\text { homogenous } \\
\text { methylation }\end{array}$ & $\begin{array}{l}\text { High } \\
\text { homogenous } \\
\text { methylation }\end{array}$ & $\begin{array}{l}\text { Total } \\
\text { positive for } \\
\text { methylation }\end{array}$ & $\begin{array}{l}\text { No } \\
\text { data }\end{array}$ \\
\hline \multirow[t]{3}{*}{$\overline{A P C}$} & Normal & $15 / 15(100)$ & $0 / 15(0)$ & $0 / 15(0)$ & $0 / 15(0)$ & $0 / 15(0)$ & $0 / 15(0)$ & $0 / 15(0)$ & 3 \\
\hline & $\begin{array}{l}\text { Pure ductal carcinoma } \\
\text { in situ (DCIS) }\end{array}$ & 29/70 (41.4) & 0/70 (0) & $4 / 70(5.7)$ & $4 / 70(5.7)$ & $27 / 70(38.6)$ & $6 / 70(8.6)$ & $37 / 70(52.9)$ & 2 \\
\hline & Mixed DCIS & $7 / 10(70)$ & $1 / 10(10)$ & 0/10 (0) & 0/10 (0) & $1 / 10(10)$ & $1 / 10(10)$ & $2 / 10(20)$ & 0 \\
\hline \multirow[t]{3}{*}{$B R C A 1$} & Normal & $17 / 17(100)$ & 0/17 (0) & 0/17 (0) & 0/17 (0) & $0 / 17(0)$ & 0/17 (0) & $0 / 17(0)$ & 1 \\
\hline & Pure DCIS & $70 / 70(100)$ & 0/70 (0) & $0 / 70(0)$ & $0 / 70(0)$ & 0/70 (0) & 0/70 (0) & 0/70 (0) & 2 \\
\hline & Mixed DCIS & $10 / 10(100)$ & $0 / 10(0)$ & $0 / 10(0)$ & $0 / 10(0)$ & $0 / 10(0)$ & $0 / 10(0)$ & 0/10 (0) & 0 \\
\hline \multirow[t]{3}{*}{$\mathrm{CDH} 1$} & Normal & 16/17 (94.1) & $0 / 17(0)$ & $1 / 17(5.9)$ & $0 / 17(0)$ & $0 / 17(0)$ & $0 / 17(0)$ & $0 / 17(0)$ & 1 \\
\hline & Pure DCIS & 62/69 (89.9) & 0/69 (0) & $5 / 69(7.2)$ & $2 / 69(2.9)$ & 0/69 (0) & $0 / 69(0)$ & 2/69 (2.9) & 3 \\
\hline & Mixed DCIS & $9 / 10(90)$ & $0 / 10(0)$ & $1 / 10(10)$ & $0 / 10(0)$ & $0 / 10(0)$ & 0/10 (0) & 0/10 (0) & 0 \\
\hline \multirow[t]{3}{*}{$\mathrm{CDH} 13$} & Normal & 16/18 (88.9) & $0 / 18(0)$ & $1 / 18(5.6)$ & $0 / 18(0)$ & $1 / 18(5.6)$ & 0/18 (0) & 1/18 (5.6) & 0 \\
\hline & Pure DCIS & $30 / 70(42.9)$ & 0/70 (0) & $0 / 70(0)$ & $32 / 70(45.7)$ & 6/70 (8.6) & $2 / 70(2.9)$ & $40 / 70(57.1)$ & 2 \\
\hline & Mixed DCIS & $6 / 10(60)$ & $1 / 10(10)$ & $0 / 10(0)$ & $2 / 10(20)$ & $0 / 10(0)$ & $1 / 10(10)$ & $3 / 10(30)$ & 0 \\
\hline \multirow[t]{3}{*}{ FOXC1 } & Normal & $16 / 17(94.1)$ & $0 / 17(0)$ & $1 / 17(5.9)$ & $0 / 17(0)$ & $0 / 17(0)$ & 0/17 (0) & 0/17 (0) & 1 \\
\hline & Pure DCIS & $59 / 70(84.3)$ & $1 / 70(1.4)$ & $3 / 70(4.3)$ & 6/70 (8.6) & $1 / 70(1.4)$ & 0/70 (0) & $7 / 70(10)$ & 2 \\
\hline & Mixed DCIS & $7 / 10(70)$ & 1/10 (10) & $0 / 10(0)$ & $1 / 10(10)$ & $1 / 10(10)$ & 0/10 (0) & 2/10 (20) & 0 \\
\hline \multirow[t]{3}{*}{ GSTP1 } & Normal & 15/16 (93.8) & 0/16 (0) & $1 / 16(6.3)$ & 0/16 (0) & 0/16 (0) & 0/16 (0) & 0/16 (0) & 2 \\
\hline & Pure DCIS & $30 / 70(42.9)$ & $4 / 70(5.7)$ & $1 / 70(1.4)$ & $10 / 70(14.3)$ & $7 / 70$ (10) & $18 / 70(25.7)$ & $35 / 70(50)$ & 2 \\
\hline & Mixed DCIS & $7 / 10(70)$ & 0/10 (0) & $0 / 10(0)$ & $1 / 10(10)$ & $1 / 10(10)$ & $1 / 10(10)$ & $3 / 10(30)$ & 0 \\
\hline \multirow[t]{3}{*}{$M A L$} & Normal & $14 / 15(93.3)$ & $0 / 15(0)$ & $1 / 15(6.7)$ & $0 / 15(0)$ & $0 / 15(0)$ & 0/15 (0) & 0/15 (0) & 3 \\
\hline & Pure DCIS & $31 / 69(44.9)$ & $5 / 69(7.2)$ & $1 / 69(1.4)$ & $32 / 69(46.3)$ & 0/69 (0) & 0/69 (0) & $32 / 69(46.3)$ & 3 \\
\hline & Mixed DCIS & $3 / 10(30)$ & 0/10 (0) & $0 / 10(0)$ & $7 / 10(70)$ & 0/10 (0) & 0/10 (0) & $7 / 10(70)$ & 0 \\
\hline \multirow[t]{3}{*}{$R A R \beta$} & Normal & $17 / 17(100)$ & 0/17 (0) & $0 / 17(0)$ & $0 / 17(0)$ & $0 / 17(0)$ & $0 / 17(0)$ & 0/17 (0) & 1 \\
\hline & Pure DCIS & $43 / 71(60.6)$ & 0/71 (0) & $1 / 71(1.4)$ & $1 / 71(1.4)$ & $16 / 71$ & $10 / 71(14.1)$ & $27 / 71(38.0)$ & 1 \\
\hline & Mixed DCIS & $7 / 10(70)$ & 0/10 (0) & $0 / 10(0)$ & $0 / 10(0)$ & $0 / 10(0)$ & $3 / 10(30)$ & $3 / 10(30)$ & 0 \\
\hline \multirow[t]{3}{*}{ RASSF1A } & Normal & 15/18 (83.3) & 1/18 (5.6) & $2 / 18(11.1)$ & 0/18 (0) & $0 / 18(0)$ & 0/18 (0) & 0/18 (0) & 0 \\
\hline & Pure DCIS & 6/70 (8.6) & 0/70 (0) & $2 / 70(2.9)$ & 0/70 (0) & $32 / 70(45.7)$ & $30 / 70(42.9)$ & $62 / 70(88.6)$ & 2 \\
\hline & Mixed DCIS & $0 / 10(0)$ & 0/10 (0) & $0 / 10(0)$ & $0 / 10(0)$ & $4 / 10(40)$ & $6 / 10(60)$ & $10 / 10(100)$ & 0 \\
\hline \multirow[t]{3}{*}{ TWIST1 } & Normal & $16 / 17(94.1)$ & 0/17 (0) & $0 / 17(0)$ & $1 / 17(5.9)$ & 0/17 (0) & 0/17 (0) & $1 / 17(5.9)$ & 1 \\
\hline & Pure DCIS & $34 / 71(47.9)$ & 4/71 (5.6) & 4/71 (5.6) & 26/71 (36.6) & $3 / 71(4.2)$ & 0/71 (0) & $29 / 71(41.4)$ & 1 \\
\hline & Mixed DCIS & $6 / 10(60)$ & 0/10 (0) & $0 / 10(0)$ & $3 / 10(30)$ & 0/10 (0) & $1 / 10(10)$ & $4 / 10(40)$ & 0 \\
\hline \multirow[t]{3}{*}{ WIF1 } & Normal & 13/18 (72.2) & 0/18 (0) & 0/18 (0) & $5 / 18(27.8)$ & 0/18 (0) & 0/18 (0) & 5/18 (27.8) & 0 \\
\hline & Pure DCIS & $31 / 70(44.3)$ & 0/70 (0) & $5 / 70(7.1)$ & $31 / 70(44.3)$ & $3 / 70(4.3)$ & 0/70 (0) & $34 / 70(48.6)$ & 2 \\
\hline & Mixed DCIS & $4 / 10(40)$ & 0/10 (0) & $1 / 10(10)$ & $3 / 10(30)$ & $2 / 10(20)$ & 0/10 (0) & $5 / 10(50)$ & 0 \\
\hline
\end{tabular}

respectively). RASSF1A methylation was significantly correlated with comedo-type necrosis $(P=0.018)$. None of the other genes assessed showed an association with nuclear grade or presence of comedo-type necrosis $(P>0.05)$. No association was found between methylation of the genes in the panel and DCIS architectural pattern $(P>0.05)$ (Table 3).
$A P C, C D H 13$ and $R A R \beta$ methylation was significantly associated with ER $\alpha$-negative DCIS $(P=0.017, P=0.017$ and $P<0.001$ respectively) and $C D H 13$ and RAR $\beta$ methylation were also significantly associated with PgR-negative DCIS $(P<0.001$ and $P=0.001)$. HER2 amplification in DCIS tumours was associated with methylation of CDH13 $(P=0.009)$, and RAR $(P=0.042) . C D H 13$ and 


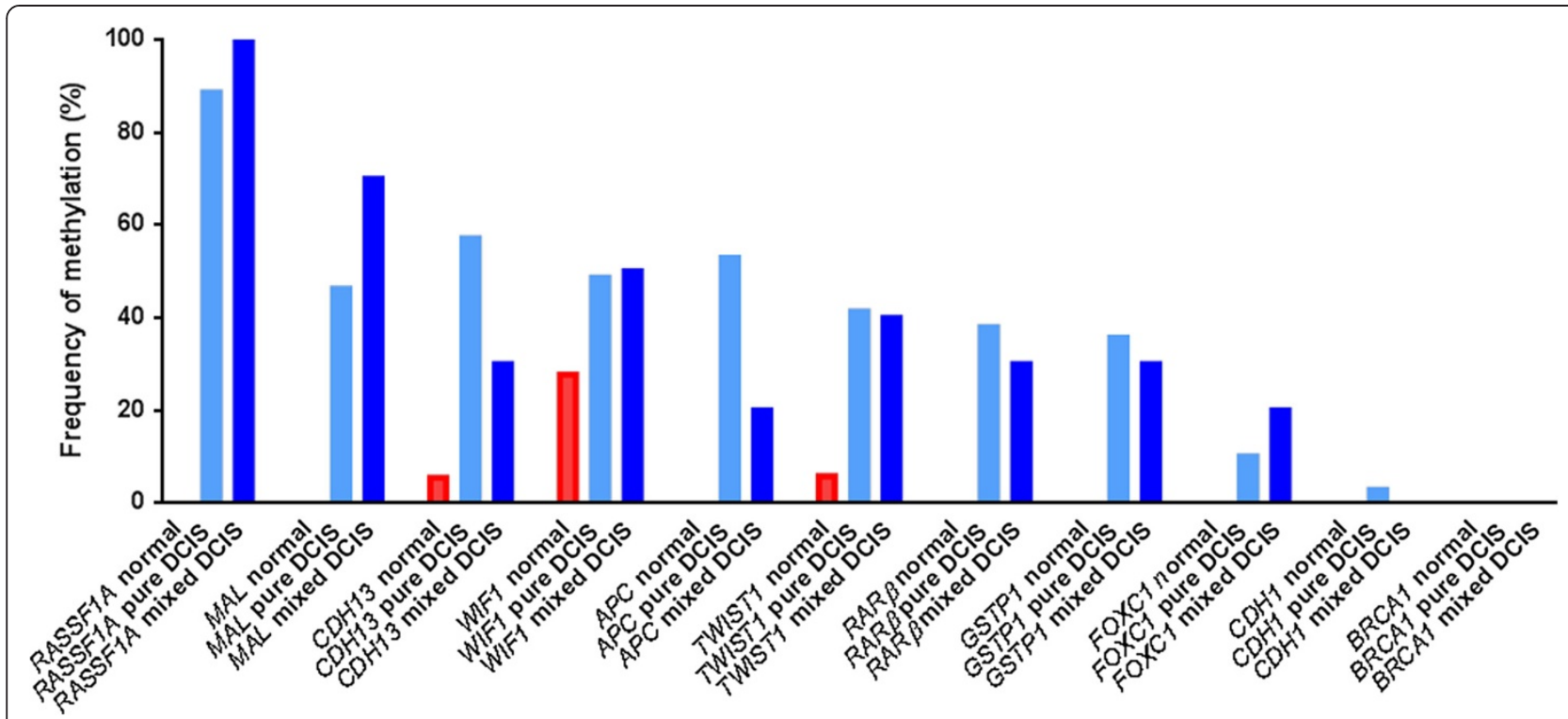

Figure 1 Frequency of methylation of each gene by sample type. DCIS, ductal carcinoma in situ.

$R A R \beta$ methylation were also significantly associated with intrinsic subtype of DCIS ( $P=0.006$ and $P=0.003$ respectively). None of the other genes assessed showed a significant relationship with hormone receptor status, HER2 amplification, or intrinsic subtype $(P>0.05)$ (Table 3$)$.

Unsupervised hierarchical cluster analysis based on methylation profile of this panel of genes demonstrated four main groups (Figure 2). Cluster 1 samples had minimal methylation, cluster 2 samples were characterized by RASSF1A methylation, cluster 3 showed APC, CDH13, and GSTP1 methylation in addition to RASSF1A, and cluster 4 samples were extensively methylated with the addition of RAR $\beta$ and WIF1 methylation. As expected, the increasing methylation is reflected in the median AMI of the clusters, the median AMI of clusters 1, 2, 3, and 4, being $0,7.4,14.5$, and 17.2 respectively $(P<0.001)$. Cluster- 4 samples were significantly associated with high nuclear grade, HER2 amplification, negative ER $\alpha$ status, negative PR status, and non-luminal intrinsic subtype $(P=0.038$, $P=0.018, P<0.001, P=0.001$, and $P<0.001$, respectively) compared with DCIS samples in the other clusters (Additional file 6). Nuclear grade remained a distinguishing feature of the other clusters, with cluster 3 containing significantly more high nuclear grade samples compared with clusters 1 and $2(P=0.004)$, and cluster 1 containing significantly more low-grade DCIS samples compared with cluster $2(P=0.013)$ (Additional file 6).

\section{Discussion}

In this study, we assessed methylation of a panel of breast cancer-associated genes in a large cohort of DCIS cases, and assessed the relationship of methylation with clinicopathological features. As expected, methylation was rarely present in adjacent morphologically normal breast epithelium. Interestingly, CDH13, TWIST1, and WIF1 were methylated in a small number of normal epithelium samples. These were also methylated in the adjacent DCIS in all but one case (WIF1 in sample S25). Several of the normal samples had more than one methylated gene. This is consistent with the possibility that methylation of these genes is an early change, and/or possibly reflects a methylation field effect in DCIS, which has been previously reported [34]. It would therefore be of interest to further compare methylation of CDH13, TWIST1, and WIF1 in DCIS, normal epithelium adjacent to DCIS, and normal epithelium from healthy breast (such as the contralateral breast) in an independent cohort to determine whether methylation of these genes observed in normal samples is a disease-related event.

No significant difference was present between pure DCIS and mixed DCIS samples. Although the absence of a difference in methylation between pure and mixed DCIS may reflect the small number of mixed DCIS samples in this cohort, it is likely that aberrant DNA methylation is an early event in breast cancer progression, with gradual accumulation of methylation changes from epithelium of normal appearance to non-malignant epithelial lesions to DCIS, while the transition from DCIS to invasive carcinoma is less likely to rely on methylation, at least not for the genes studied here $[5,7,9,35,36]$.

Of particular interest was the total absence of $B R C A 1$ methylation in this cohort. Given a frequency of approximately $20 \% B R C A 1$ methylation in invasive carcinoma [37], this suggests that tumours driven by BRCA1 
Table 3 Relationship between methylation and phenotypic features of digital carcinoma in situ

\begin{tabular}{|c|c|c|c|c|c|c|c|c|c|c|c|}
\hline & \multicolumn{11}{|l|}{ Methylated gene } \\
\hline & $\overline{A P C}$ & $B R C A 1$ & $\mathrm{CDH} 1$ & $\mathrm{CDH13}$ & FOXC1 & GSTP1 & $M A L$ & RARB & RASSF1A & TWIST1 & WIF1 \\
\hline High nuclear grade & $\begin{array}{l}\text { 64.9\% HG, 34.9\% } \\
\text { non-HG } \boldsymbol{P}=\mathbf{0 . 0 1 3}\end{array}$ & $P=1.000$ & $P=1.000$ & $\begin{array}{l}67.6 \% \mathrm{HG}, \quad 41.9 \% \\
\text { non-HG } \boldsymbol{P}=\mathbf{0 . 0 2 6}\end{array}$ & $P=0.073$ & $P=0.178$ & $P=1.000$ & $P=0.106$ & $P=0.275$ & $P=1.000$ & $P=0.116$ \\
\hline Architectural pattern & $P=0.620$ & $P=1.000$ & $P=0.907$ & $P=0.256$ & $P=0.596$ & $P=0.519$ & $P=0.399$ & $P=0.365$ & $P=0.254$ & $P=0.311$ & $P=0.402$ \\
\hline Comedo necrosis & $P=0.175$ & $P=1.000$ & $P=0.503$ & $P=0.500$ & $P=0.159$ & $P=0.498$ & $P=0.652$ & $P=1.000$ & $\begin{array}{l}100 \% \text { CN, } 82.6 \% \\
\text { non-CN } \boldsymbol{P}=\mathbf{0 . 0 1 8}\end{array}$ & $P=0.253$ & $P=0.824$ \\
\hline ERa & $\begin{array}{l}41.5 \% \text { ERa+, } 75 \% \text { ERa- } \\
\boldsymbol{P}=\mathbf{0 . 0 1 7}\end{array}$ & $P=1.000$ & $P=0.481$ & $\begin{array}{l}47.2 \% E R a+, 80 \% \\
E R a-P=\mathbf{P . 0 1 7}\end{array}$ & $P=0.246$ & $P=0.794$ & $P=0.111$ & $\begin{array}{l}27.8 \% \mathrm{ERa}+, 75 \% \\
\mathrm{ERa}-\boldsymbol{P}<\mathbf{0 . 0 0 1}\end{array}$ & $P=0.336$ & $P=0.604$ & $P=0.794$ \\
\hline $\mathrm{PgR}$ & $P=0.236$ & $P=1.000$ & $P=1.000$ & $\begin{array}{l}37.2 \% \text { PgR+, } 83.3 \% \\
\text { PgR- } P<\mathbf{0 . 0 0 1}\end{array}$ & $P=0.473$ & $P=1.000$ & $P=0.230$ & $\begin{array}{l}23.3 \% \text { PgR+, } 64.5 \% \\
\text { PgR- } P=\mathbf{0 . 0 0 1}\end{array}$ & $P=1.000$ & $P=1.000$ & $P=0.346$ \\
\hline HER2 & $P=0.607$ & $P=1.000$ & $P=1.000$ & $\begin{array}{l}81.0 \% \text { HER2, } 46.2 \% \\
\text { non-HER2 } \boldsymbol{P}=\mathbf{0 . 0 0 9}\end{array}$ & $P=0.711$ & $P=0.302$ & $P=0.305$ & $\begin{array}{l}59.1 \% \text { HER2, } 32.7 \% \\
\text { non-HER2 } \boldsymbol{P}=\mathbf{0 . 0 4 2}\end{array}$ & $P=0.173$ & $P=0.446$ & $P=0.607$ \\
\hline Intrinsic subtype & $P=0.184$ & $P=1.000$ & $P=0.252$ & $\begin{array}{l}\text { Basal } 50 \% \text {, HER2 } 81.0 \% \text {, } \\
\text { Luminal } 39.5 \% \text {, Negative } \\
85.7 \% \boldsymbol{P}=\mathbf{0 . 0 0 6}\end{array}$ & $P=0.136$ & $P=0.08$ & $P=0.368$ & $\begin{array}{l}\text { Basal } 100 \% \text {, HER2 } 59.1 \% \text {, } \\
\text { Luminal } 23.3 \% \text {, Negative } \\
71.4 \% \boldsymbol{P}=\mathbf{0 . 0 0 3}\end{array}$ & $P=0.113$ & $P=0.597$ & $P=0.111$ \\
\hline
\end{tabular}

$\mathrm{HG}$, high nuclear grade, $\mathrm{CN}$, comedo necrosis. Detailed results of all analyses are tabulated in Additional file 6 . 


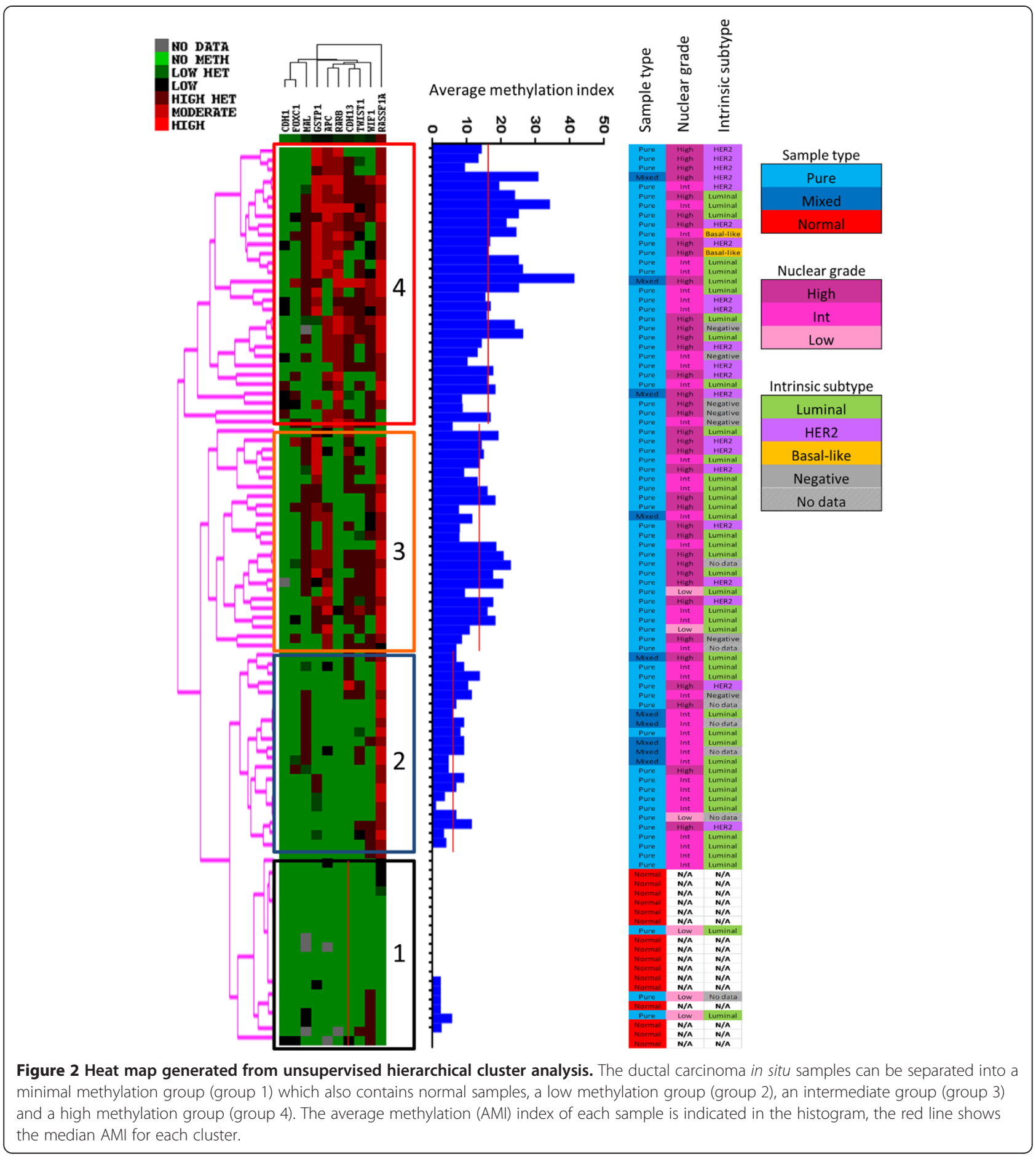

methylation either rarely pass through a DCIS phase or have an exceedingly rapid transit through one, a notion supported by observation that DCIS is rare in carriers with $B R C A 1$ germline mutations [38,39].

Cluster analysis based on methylation profile divided our DCIS cohort into four groups, which were phenotypically distinguished by nuclear grade, and in particular, the high-methylation cluster (cluster 4), being associated with additional aggressive phenotypic features including negative hormone receptor status, HER2 amplification, and non-luminal intrinsic subtype. Our results suggest that methylation has a stronger role in the biology of certain DCIS cases than others and perhaps differences in methylation patterns could be used to classify DCIS cases in a clinically significant way. Indeed, in invasive breast cancers, a breast $\mathrm{CpG}$ island methylator phenotype (B-CIMP) 
has been described and associated with clinical outcome [40] and methylation profile has been shown to be related to intrinsic subtype [41-43].

Methylation of APC, CDH13, RAR $\beta$ and RASSF1A was variably significantly associated with conventional aggressive characteristics including high nuclear grade, comedo necrosis, negative ER $\alpha$ status, negative PgR status, HER2 amplification, and intrinsic subtype. The association between methylation of these genes and adverse phenotypic features in DCIS is in keeping with the role of these genes as tumour suppressor genes. APC is a component of the Wnt signaling pathway, where it forms part of a protein complex leading to the phosphorylation and degradation of $\beta$-catenin in the absence of Wnt binding [44]. CDH13 negatively controls tumour growth and invasiveness and promotes tumour neovascularization [45], while RAR $\beta$ is required for the tumour suppressive effects of retinoids [46] and RASSF1A, a key player in the Hippo tumour suppressor pathway, has roles in cell cycle regulation, apoptosis and microtubule stability [47]. Indeed, in invasive breast cancer, the presence of $R A R \beta$ methylation in both tumour and serum has been associated with poor disease-free and overall survival $[48,49]$, while the presence of RASSF1A and $A P C$ methylation in pre-operative serum samples predicts for poorer overall survival [50,51], and $A P C$ methylation in breast cancer tissue is associated with reduced time to recurrence [17]. Similarly, a recent meta-analysis demonstrated a relationship between RASSF1A methylation and higher risk of relapse and poorer survival [52]. While CDH13 methylation has not yet been directly associated with prognosis in breast cancer, $\mathrm{CDH} 13$ methylation has been associated with HER2 amplification [52] and negative PgR status [15] in invasive breast carcinoma, although the latter relationship was not confirmed in a subsequent study by the same group [53].

Unfortunately, no long-term follow-up data are available for the DCIS cases in our current study to determine whether methylation is associated with outcome in patients with DCIS. It would thus be of great interest to validate the methylation status of these genes in a large independent series with long-term follow up, annotated for known prognostic factors such as nuclear grade, margin status, and adjuvant therapy, to investigate the relationship of methylation with patient outcome.

When comparing our results with the data in the literature, we were unable to confirm the previously published associations of $R A R \beta[5,6]$, and $C D H 1$ [6] methylation with nuclear grade, higher FOXC1 $[7,8]$, GSTP1 $[7,8]$, and RASSF1A $[7,8]$ methylation levels with positive ER $\alpha$ status, higher GSTP1 methylation levels with positive PgR status [7], and higher RASSF1A methylation levels with HER2 amplification [8], although trends toward an association of $R A R \beta$ with nuclear grade, and RASSF1A with positive ER $\alpha$ status and HER2 amplification were also seen in our cohort (Additional file 6). These differences are likely to be due to the use of different methodologies and study populations. We have used a robust and reproducible semiquantitative method of methylation analysis, whereas the other studies have either used methylation-specific assays $[5,6]$ or fully quantitative methodologies, which have been performed in an exceedingly small cohorts that are likely to give rise to significant bias $[7,8]$. Furthermore, our cohort consists of predominantly pure DCIS samples whereas other studies generally have examined mixed DCIS and invasive cancers $[7,8]$.

\section{Conclusions}

In this study we have demonstrated a significant association between methylated genes and known prognostic features in DCIS with a candidate-gene panel approach. In particular, this is the only study focused on pure DCIS that has correlated methylation with intrinsic phenotype. We report for the first time an association of $\mathrm{CDH} 13$ methylation with nuclear grade and hormone receptor status in DCIS. We have also established a new classification method based on methylation load using multiple markers. We have further shown that DNA methylation can be assessed even with small quantities of degraded FFPE DNA, enabling its use as a robust biomarker in DCIS. The next step will therefore be to investigate the role of methylation as a prognostic biomarker in a large independent cohort of pure DCIS cases with long-term follow up. It is also likely that as with invasive carcinoma some methylated genes may be of use as predictive biomarkers of hormonal therapy [54], a further avenue of investigation that warrants research effort.

\section{Additional files}

\section{Additional file 1: Patient flow in study.}

Additional file 2: Examples of methylation-sensitive high-resolution melting (MS-HRM patterns).

Additional file 3: Methylation-sensitive high-resolution melting (MS-HRM) primer sequences.

Additional file 4: PCR and methylation-sensitive high-resolution melting (MS-HRM) conditions.

Additional file 5: Methylation-sensitive high-resolution melting (MS-HRM) results for each sample.

Additional file 6: Methylation and ductal carcinoma in situ (DCIS) phenotype data.

\section{Abbreviations}

AMl: average methylation index; DCIS: ductal carcinoma in situ; ERa: estrogen receptor alpha; FFPE: Formalin fixed, paraffin embedded;

H\&E: haematoxylin and eosin; HER2: human epidermal growth factor receptor-2; IHC: immunohistochemistry/immunohistochemical;

MS-HRM: methylation-sensitive high-resolution melting; PgR: progesterone receptor; SISH: silver in situ hybridisation; TMA: tissue microarray; WGA: whole genome amplified. 


\section{Competing interests}

The authors declare that they have no competing interests.

\section{Authors' contributions}

J-MBP identified cases, prepared samples, obtained clinicopathological data, performed methylation assays, interpreted and analyzed data, and wrote the manuscript. SD and EAT interpreted data, wrote and edited the manuscript. DJB prepared sections for microdissection, constructed tissue microarrays, interpreted and analyzed data, wrote and edited the manuscript. NJ optimized and performed immunohistochemical staining of samples, wrote and edited the manuscript. $\mathrm{AB}$ and $\mathrm{AH}$ identified cases, constructed tissue microarrays, obtained clinicopathological data and constructed a database, wrote and edited the manuscript. EM, CSL, and SAO conceptualized the project, identified cases, obtained clinicopathological data and constructed a database, provided analysis, wrote and edited the manuscript. AD conceptualized the project, designed methylation assays, interpreted data provided analysis, wrote and edited the manuscript. SBF conceptualized the project, wrote and edited the manuscript, provided project oversight and coordination, and analysis. AD and SBF share senior authorship of this manuscript. All authors read and approved the final manuscript.

\section{Authors' information}

Alexander Dobrovic and Stephen B Fox are joint last authors.

\section{Acknowledgements}

We thank Ida Candiloro and Hongdo Do for advice on primer design and for access to unpublished primer sequences, MS-HRM assay optimization and interpretation of MS-HRM data. This project is funded by grants to SBF and AD from Cancer Australia and the National Breast Cancer Foundation, Australia, to AD from the Cancer Council of Victoria and the Department of Defense Breast Cancer Research Program under award number W81XWH-051-0500, and to SOT from The Cancer Institute NSW, and the Sydney Breast Cancer Foundation.

\section{Author details}

'Department of Pathology, Peter MacCallum Cancer Centre, St Andrews Place, Melbourne, VIC 3002, Australia. ${ }^{2}$ Department of Pathology, University of Melbourne, Grattan Street, Parkville, Melbourne, VIC 3010, Australia. ${ }^{3}$ Sir Peter MacCallum Department of Oncology, University of Melbourne, Grattan Street, Parkville, Melbourne, VIC 3010, Australia. ${ }^{4}$ The Kinghorn Cancer Centre and Garvan Institute of Medical Research, Victoria Street, Darlinghurst, NSW 2010, Australia. ${ }^{5}$ Department of Anatomical Pathology, South Eastern Area Pathology Service, St George Hospital, Gray Street, Kogarah, NSW 2217, Australia. ${ }^{6}$ School of Medical Sciences, University of New South Wales, Kensington, NSW 2052, Australia. ${ }^{7}$ Department of Tissue Pathology, Royal Prince Alfred Hospital, Missenden Road, Camperdown, NSW 2050, Australia. ${ }^{8}$ Discipline of Pathology, School of Medicine, University of Western Sydney, Campbelltown, NSW 2751, Australia. ${ }^{9}$ Cancer Pathology, Bosch Institute, University of Sydney, Sydney, NSW 2006, Australia. ${ }^{10}$ Sydney Medical School, University of Sydney, Sydney, NSW 2006, Australia. ${ }^{11}$ Translational Genomics \& Epigenomics Laboratory, Ludwig Institute for Cancer Research, Olivia Newton-John Cancer \& Wellness Centre, Heidelberg, VIC 3084, Australia.

Received: 26 February 2014 Accepted: 30 July 2014

Published online: 21 October 2014

\section{References}

1. Wang SY, Shamliyan T, Virnig BA, Kane R: Tumor characteristics as predictors of local recurrence after treatment of ductal carcinoma in situ: a meta-analysis. Breast Cancer Res Treat 2011, 127:1-14.

2. Lari SA, Kuerer HM: Biological markers in DCIS and risk of breast recurrence: a systematic review. J Cancer 2011, 2:232-261.

3. Independent UKPoBCS: The benefits and harms of breast cancer screening: an independent review. Lancet 2012, 380:1778-1786.

4. Heichman KA, Warren JD: DNA methylation biomarkers and their utility for solid cancer diagnostics. Clin Chem Lab Med 2012, 50:1707-1721.

5. Park SY, Kwon HJ, Lee HE, Ryu HS, Kim SW, Kim JH, Kim IA, Jung N, Cho NY, Kang GH: Promoter CpG island hypermethylation during breast cancer progression. Virchows Arch 2011, 458:73-84.

6. Lee JS, Fackler MJ, Teo WW, Lee JH, Choi C, Park MH, Yoon JH, Zhang Z, Argani P, Sukumar S: Quantitative promoter hypermethylation profiles of ductal carcinoma in situ in North American and Korean women: Potential applications for diagnosis. Cancer Biol Ther 2008, 7:1398-1406.

7. Muggerud AA, Ronneberg JA, Warnberg F, Botling J, Busato F, Jovanovic J, Solvang H, Bukholm I, Borresen-Dale AL, Kristensen VN, Sorlie T, Tost J: Frequent aberrant DNA methylation of ABCB1, FOXC1, PPP2R2B and PTEN in ductal carcinoma in situ and early invasive breast cancer. Breast Cancer Res 2010, 12:R3.

8. Klajic J, Fleischer T, Dejeux E, Edvardsen H, Warnberg F, Bukholm I, Lonning PE, Solvang H, Borresen-Dale AL, Tost J, Kristensen VN: Quantitative DNA methylation analyses reveal stage dependent DNA methylation and association to clinico-pathological factors in breast tumors. BMC Cancer 2013, 13:456.

9. Moelans $C B$, Verschuur-Maes $A H$, van Diest PJ: Frequent promoter hypermethylation of BRCA2, CDH13, MSH6, PAX5, PAX6 and WT1 in ductal carcinoma in situ and invasive breast cancer. J Pathol 2011, 225:222-231.

10. Lehmann U, Langer F, Feist H, Glockner S, Hasemeier B, Kreipe H: Quantitative assessment of promoter hypermethylation during breast cancer development. Am J Pathol 2002, 160:605-612.

11. Pang JMB, Dobrovic A, Fox SB: DNA methylation in ductal carcinoma in situ of the breast. Breast Cancer Res 2013, 15:3.

12. Cancer Genome Atlas N: Comprehensive molecular portraits of human breast tumours. Nature 2012, 490:61-70.

13. Wu L, Wang F, Xu R, Zhang S, Peng X, Feng Y, Wang J, Lu C: Promoter methylation of BRCA1 in the prognosis of breast cancer: a meta-analysis. Breast Cancer Res Treat 2013, 142:619-627.

14. Xu X, Gammon MD, Zhang Y, Bestor TH, Zeisel SH, Wetmur JG, Wallenstein S, Bradshaw PT, Garbowski G, Teitelbaum SL, Neugut Al, Santella RM, Chen J: BRCA1 promoter methylation is associated with increased mortality among women with breast cancer. Breast Cancer Res Treat 2009, 115:397-404.

15. Feng W, Shen L, Wen S, Rosen DG, Jelinek J, Hu X, Huan S, Huang M, Liu J, Sahin AA, Hunt KK, Bast RC Jr, Shen Y, Issa JP, Yu Y: Correlation between $\mathrm{CpG}$ methylation profiles and hormone receptor status in breast cancers. Breast Cancer Res 2007, 9:R57.

16. Horne HN, Lee PS, Murphy SK, Alonso MA, Olson JA Jr, Marks JR: Inactivation of the MAL gene in breast cancer is a common event that predicts benefit from adjuvant chemotherapy. Mol Cancer Res 2009, 7:199-209.

17. Cheol Kim D, Thorat MA, Lee MR, Cho SH, Vasiljevic N, Scibior-Bentkowska D, Wu K, Ahmad AS, Duffy S, Cuzick JM, Lorincz AT: Quantitative DNA methylation and recurrence of breast cancer: a study of 30 candidate genes. Cancer Biomark 2012, 11:75-88.

18. Trifa F, Karray-Chouayekh S, Jmal E, Jmaa ZB, Khabir A, Sellami-Boudawara T, Frikha M, Daoud J, Mokdad-Gargouri R: Loss of WIF-1 and Wnt5a expression is related to aggressiveness of sporadic breast cancer in Tunisian patients. Tumour Biol 2013, 34:1625-1633.

19. Schnitt SJ AC, Britton P, Ellis IO, Lakhani SR, Morrow M, Palazzo J, Reynolds C, Rutgers E, Simpson J, van de Vijver MJ, Vincent-Salomon A: Ductal carcinoma in situ. In WHO classification of tumours of the breast. 4th edition. Edited by Lakhani SR, Ellis IO, Schnitt SJ, Tan PH, van de Vijver MJ. Lyon: International Agency for Research on Cancer; 2012:90-94.

20. Yan M, Xu H, Waddell N, Shield-Artin K, Haviv I, kConFab a, McKay MJ, Fox SB: Enhanced RAD21 cohesin expression confers poor prognosis in BRCA2 and BRCAX, but not BRCA1 familial breast cancers. Breast Cancer Res 2012, 14:R69.

21. Deb S, Jene N, Kconfab I, Fox SB: Genotypic and phenotypic analysis of familial male breast cancer shows under representation of the HER2 and basal subtypes in BRCA-associated carcinomas. BMC Cancer 2012, 12:510.

22. Wolff AC, Hammond ME, Schwartz JN, Hagerty KL, Allred DC, Cote RJ, Dowsett M, Fitzgibbons PL, Hanna WM, Langer A, McShane LM, Paik S, Pegram MD, Perez EA, Press MF, Rhodes A, Sturgeon C, Taube SE, Tubbs R, Vance $\mathrm{GH}$, van de Vijver M, Wheeler TM, Hayes DF, American Society of Clinical O, College of American P: American Society of Clinical Oncology/ College of American Pathologists guideline recommendations for human epidermal growth factor receptor 2 testing in breast cancer. J Clin Oncol 2007, 25:118-145.

23. Nielsen TO, Hsu FD, Jensen $K$, Cheang M, Karaca G, Hu Z, Hernandez-Boussard T, Livasy C, Cowan D, Dressler L, Akslen LA, Ragaz J, Gown AM, Gilks CB, van de Rijn M, Perou CM: Immunohistochemical and clinical characterization of the 
basal-like subtype of invasive breast carcinoma. Clin Cancer Res 2004, 10:5367-5374.

24. Cheang MC, Voduc D, Bajdik C, Leung S, McKinney S, Chia SK, Perou CM, Nielsen TO: Basal-like breast cancer defined by five biomarkers has superior prognostic value than triple-negative phenotype. Clin Cancer Res 2008, 14:1368-1376.

25. Clark SE, Warwick J, Carpenter R, Bowen RL, Duffy SW, Jones JL: Molecular subtyping of DCIS: heterogeneity of breast cancer reflected in pre-invasive disease. Br J Cancer 2011, 104:120-127.

26. Livasy CA, Perou CM, Karaca G, Cowan DW, Maia D, Jackson S, Tse CK, Nyante S, Millikan RC: Identification of a basal-like subtype of breast ductal carcinoma in situ. Hum Pathol 2007, 38:197-204.

27. Zhou W, Jirstrom K, Johansson C, Amini RM, Blomqvist C, Agbaje O, Warnberg F: Long-term survival of women with basal-like ductal carcinoma in situ of the breast: a population-based cohort study. BMC Cancer 2010, 10:653.

28. Huang KT, Dobrovic A, Yan M, Karim RZ, Lee CS, Lakhani SR, Fox SB: DNA methylation profiling of phyllodes and fibroadenoma tumours of the breast. Breast Cancer Res Treat 2010, 124:555-565.

29. Wojdacz TK, Dobrovic A: Methylation-sensitive high resolution melting (MS-HRM): a new approach for sensitive and high-throughput assessment of methylation. Nucleic Acids Res 2007, 35:e41.

30. Mikeska T, Dobrovic A: Methylation-sensitive high resolution melting for the rapid analysis of DNA methylation. In Epigenetics: a reference manual. Edited by Craig JaW NC. Norwich: Horizon Scientific Press; 2011:325-335.

31. Candiloro IL, Mikeska T, Dobrovic A: Assessing combined methylation-sensitive high resolution melting and pyrosequencing for the analysis of heterogeneous DNA methylation. Epigenetics 2011 6:500-507.

32. Wojdacz TK, Hansen LL, Dobrovic A: A new approach to primer design for the control of PCR bias in methylation studies. BMC Res Notes 2008, 1:54

33. Fackler MJ, Malone K, Zhang Z, Schilling E, Garrett-Mayer E, Swift-Scanlan T, Lange J, Nayar R, Davidson NE, Khan SA, Sukumar S: Quantitative multiplex methylation-specific PCR analysis doubles detection of tumor cells in breast ductal fluid. Clin Cancer Res 2006, 12:3306-3310.

34. Yan PS, Venkataramu C, Ibrahim A, Liu JC, Shen RZ, Diaz NM, Centeno B, Weber F, Leu YW, Shapiro CL, Eng C, Yeatman TJ, Huang TH: Mapping geographic zones of cancer risk with epigenetic biomarkers in normal breast tissue. Clin Cancer Res 2006, 12:6626-6636.

35. van Hoesel AQ, Sato Y, Elashoff DA, Turner RR, Giuliano AE, Shamonki JM, Kuppen PJ, van de Velde CJ, Hoon DS: Assessment of DNA methylation status in early stages of breast cancer development. Br J Cancer 2013, 108:2033-2038.

36. Verschuur-Maes $A H$, de Bruin PC, van Diest PJ: Epigenetic progression of columnar cell lesions of the breast to invasive breast cancer. Breast Cancer Res Treat 2012, 136:705-715.

37. Bianco T, Chenevix-Trench G, Walsh DC, Cooper JE, Dobrovic A: Tumour-specific distribution of BRCA1 promoter region methylation supports a pathogenetic role in breast and ovarian cancer. Carcinogenesis 2000, 21:147-151.

38. Breast Cancer Linkage Consortium: Pathology of familial breast cancer: differences between breast cancers in carriers of BRCA1 or BRCA2 mutations and sporadic cases. Lancet 1997, 349:1505-1510.

39. Lakhani SR, Jacquemier J, Sloane JP, Gusterson BA, Anderson TJ, van de Vijver MJ, Farid LM, Venter D, Antoniou A, Storfer-Isser A, Smyth E, Steel CM, Haites N, Scott RJ, Goldgar D, Neuhausen S, Daly PA, Ormiston W, McManus R, Scherneck S, Ponder BA, Ford D, Peto J, Stoppa-Lyonnet D, Bignon YJ, Struewing JP, Spurr NK, Bishop DT, Klijn JG, Devilee P, et al: Multifactorial analysis of differences between sporadic breast cancers and cancers involving BRCA1 and BRCA2 mutations. J Natl Cancer Inst 1998, 90:1138-1145

40. Fang F, Turcan S, Rimner A, Kaufman A, Giri D, Morris LG, Shen R, Seshan V, Mo Q, Heguy A, Baylin SB, Ahuja N, Viale A, Massague J, Norton L, Vahdat LT, Moynahan ME, Chan TA: Breast cancer methylomes establish an epigenomic foundation for metastasis. Sci Transl Med 2011, 3:75ra25.

41. Holm K, Hegardt C, Staaf J, Vallon-Christersson J, Jonsson G, Olsson H, Borg A, Ringner M: Molecular subtypes of breast cancer are associated with characteristic DNA methylation patterns. Breast Cancer Res 2010, 12:R36.
42. Bardowell SA, Parker J, Fan C, Crandell J, Perou CM, Swift-Scanlan T: Differential methylation relative to breast cancer subtype and matched normal tissue reveals distinct patterns. Breast Cancer Res Treat 2013, 142:365-380.

43. Suijkerbuijk KP, Fackler MJ, Sukumar S, van Gils $C H$, van Laar T, van der Wall E, Vooijs M, van Diest PJ: Methylation is less abundant in BRCA1-associated compared with sporadic breast cancer. Ann Oncol 2008, 19:1870-1874.

44. Klarmann GJ, Decker A, Farrar WL: Epigenetic gene silencing in the Wnt pathway in breast cancer. Epigenetics 2008, 3:59-63.

45. Andreeva AV, Kutuzov MA: Cadherin 13 in cancer. Genes Chromosomes Cancer 2010, 49:775-790.

46. Alvarez S, Germain P, Alvarez R, Rodriguez-Barrios F, Gronemeyer H, de Lera AR: Structure, function and modulation of retinoic acid receptor beta, a tumor suppressor. Int J Biochem Cell Biol 2007, 39:1406-1415.

47. Agathanggelou A, Cooper WN, Latif F: Role of the Ras-association domain family 1 tumor suppressor gene in human cancers. Cancer Res 2005, 65:3497-3508.

48. Mirza S, Sharma G, Parshad R, Srivastava A, Gupta SD, Ralhan R: Clinical significance of promoter hypermethylation of ERbeta and RARbeta2 in tumor and serum DNA in Indian breast cancer patients. Ann Surg Oncol 2012, 19:3107-3115.

49. Sharma G, Mirza S, Yang YH, Parshad R, Hazrah P, Datta Gupta S, Ralhan R: Prognostic relevance of promoter hypermethylation of multiple genes in breast cancer patients. Cell Oncol 2009, 31:487-500.

50. Muller HM, Widschwendter A, Fiegl H, Ivarsson L, Goebel G, Perkmann E, Marth C, Widschwendter M: DNA methylation in serum of breast cancer patients: an independent prognostic marker. Cancer Res 2003, 63:7641-7645.

51. Muller HM, Fiegl H, Widschwendter A, Widschwendter M: Prognostic DNA methylation marker in serum of cancer patients. Ann NY Acad Sci 2004, 1022:44-49.

52. Jiang $Y$, Cui L, Chen WD, Shen SH, Ding LD: The prognostic role of RASSF1A promoter methylation in breast cancer: a meta-analysis of published data. PLoS One 2012, 7:e36780.

53. Xu J, Shetty PB, Feng W, Chenault C, Bast RC Jr, Issa JP, Hilsenbeck SG, Yu Y: Methylation of HIN-1, RASSF1A, RIL and CDH13 in breast cancer is associated with clinical characteristics, but only RASSF1A methylation is associated with outcome. BMC Cancer 2012, 12:243.

54. Harbeck N, Nimmrich I, Hartmann A, Ross JS, Cufer T, Grutzmann R, Kristiansen G, Paradiso A, Hartmann O, Margossian A, Martens J, Schwope I, Lukas A, Muller V, Milde-Langosch K, Nahrig J, Foekens J, Maier S, Schmitt M, Lesche R: Multicenter study using paraffin-embedded tumor tissue testing PITX2 DNA methylation as a marker for outcome prediction in tamoxifen-treated, node-negative breast cancer patients. J Clin Oncol 2008, 26:5036-5042.

\section{doi:10.1186/s13058-014-0423-9}

Cite this article as: Pang et al:: Methylation profiling of ductal carcinoma in situ and its relationship to histopathological features. Breast Cancer Research 2014 16:423.

\section{Submit your next manuscript to BioMed Central and take full advantage of:}

- Convenient online submission

- Thorough peer review

- No space constraints or color figure charges

- Immediate publication on acceptance

- Inclusion in PubMed, CAS, Scopus and Google Scholar

- Research which is freely available for redistribution 